Article

\title{
High Temperature Stable Anatase Phase Titanium Dioxide Films Synthesized by Mist Chemical Vapor Deposition
}

\author{
Qiang Zhang ${ }^{1} \mathbb{D}$ and Chaoyang $\mathrm{Li}^{1,2, *}$ \\ 1 School of Systems Engineering, Kochi University of Technology, Kami, Kochi 782-8502, Japan; \\ 216005z@gs.kochi-tech.ac.jp \\ 2 Center for Nanotechnology, Kochi University of Technology, Kami, Kochi 782-8502, Japan \\ * Correspondence: li.chaoyang@kochi-tech.ac.jp; Tel.: +81-887-57-2106
}

Received: 31 March 2020; Accepted: 6 May 2020; Published: 9 May 2020

check for updates

\begin{abstract}
Pure anatase-phase titanium dioxide films stable up to high temperatures were successfully fabricated by the mist chemical vapor deposition method. A post-annealing treatment of the synthesized films was carried out in oxygen atmosphere in the temperature range from 600 to $1100{ }^{\circ} \mathrm{C}$ and no anatase to rutile transformation was observed up to $1000^{\circ} \mathrm{C}$. Based on the grazing incidence X-ray diffraction data, the average crystallite size of the titanium dioxide films increased gradually with increasing annealing temperature. The structural analysis revealed that the high thermal stability of the anatase phase can be attributed to the small crystallite size and a sheet-like grain structure. An incomplete anatase to rutile transformation was observed after annealing at $1100{ }^{\circ} \mathrm{C}$.
\end{abstract}

Keywords: anatase; titanium dioxide; thin film; thermal stability; mist chemical vapor deposition

\section{Introduction}

Titanium dioxide $\left(\mathrm{TiO}_{2}\right)$ is one of the most promising semiconductor materials due to its unique properties such as a wide bandgap, abundance in nature, and high physical and chemical stability [1,2]. $\mathrm{TiO}_{2}$ has been extensively investigated for potential application in photocatalysts, photovoltaic devices and gas sensors [3]. Generally, $\mathrm{TiO}_{2}$ has three crystalline phases: anatase, rutile, and brookite. Compared with other phases of $\mathrm{TiO}_{2}$, anatase phase $\mathrm{TiO}_{2}$ has better photocatalytic and photovoltaic activity because of its larger bandgap and higher surface energy. However, anatase is the metastable phase and can easily transform to rutile phase, the most stable phase of $\mathrm{TiO}_{2}$, after high temperature heating. Reported research has shown that the anatase to rutile transformation occurs at temperatures between 450 and $850{ }^{\circ} \mathrm{C}$, depending on fabrication method and precursors [4-8]. Various methods such as metal dopant and morphology control have been investigated to resist the anatase-rutile transformation $[9,10]$. However, until now, there was little report on successfully fabricating pure anatase $\mathrm{TiO}_{2}$ film stabilized at high temperature of over $900{ }^{\circ} \mathrm{C}$. In order to apply anatase phase $\mathrm{TiO}_{2}$ for various environmental applications such as gas sensors, anti-microbial sanitary wares, and self-cleaning ceramic tiles, high temperature stable anatase $\mathrm{TiO}_{2}$ without phase transformation is essential $[11,12]$. Therefore, the development of a high temperature stable (above $1000^{\circ} \mathrm{C}$ ) anatase phase $\mathrm{TiO}_{2}$ is desirable.

The anatase to rutile transformation has been investigated by a number of groups [9,10,13-22]. According to the literature $[9,10,13-21]$, the anatase to rutile transformation could be influenced by several factors including particle size, particle shape, and the presence of $\{112\}$ facets. Related researches predicted that anatase became more stable than rutile when the particle size was smaller than the critical size $(6.9 \sim 22.7 \mathrm{~nm})[13,14]$. Furthermore, it has been reported that rutile could easily nucleate at 
$\{112\}$ twin interfaces during the anatase to rutile transformation [15-19]. As a result, the presence of

$\{112\}$ facets in anatase phase $\mathrm{TiO}_{2}$ will decrease the thermal stability of anatase phase $\mathrm{TiO}_{2}$.

According to our previous research, mist chemical vapor deposition (mist CVD) method was found to have specific advantages in terms of precise growth controllability, large area deposition and simplicity to synthesize $\mathrm{TiO}_{2}$ thin films $[23,24]$. In this research, the mist CVD method was used to synthesize $\mathrm{TiO}_{2}$ thin film, and the thermal stability of obtained $\mathrm{TiO}_{2}$ films was investigated.

\section{Materials and Methods}

\subsection{Fabrication of $\mathrm{TiO}_{2}$ Thin Films}

$\mathrm{TiO}_{2}$ thin films with a thickness of $300 \mathrm{~nm}$ were deposited on quartz glass substrate (MITORIKA Co., Ltd., Mito, Japan) by mist CVD. The deposition condition of $\mathrm{TiO}_{2}$ films is shown in Table 1 . A solution of precursor was prepared by dissolving titanium tetraisopropoxide (TTIP, purity $>95.0 \%$, Wako Pure Chemical Industries, Ltd., Osaka, Japan) in ethanol (purity $>99.5 \%$, Wako Pure Chemical Industries, Ltd., Osaka, Japan). The concentration of TTIP was $0.10 \mathrm{~mol} / \mathrm{L}$. The solution was ultrasonically atomized by ultrasonic transducers $(2.4 \mathrm{MHz})$. Subsequently, the mist droplets of precursor were transferred to the reaction chamber using compressed air as a carrier gas and dilution gas, with flow rates controlled at $2.5 \mathrm{~L} / \mathrm{min}$ and $4.5 \mathrm{~L} / \mathrm{min}$ respectively. The substrate was set in the reaction chamber, which was heated and kept at $400{ }^{\circ} \mathrm{C}$.

Table 1. Deposition condition of $\mathrm{TiO}_{2}$ films.

\begin{tabular}{cc} 
Solute & TTIP \\
Solvent & Ethanol \\
Concentration $(\mathbf{m o l} / \mathrm{L})$ & 0.10 \\
Deposition temperature $\left({ }^{\circ} \mathrm{C}\right)$ & 400 \\
Carrier gas, flow rate $(\mathrm{L} / \mathrm{min})$ & Compressed air, 2.5 \\
Dilution gas, flow rate $(\mathrm{L} / \mathrm{min})$ & Compressed air, 4.5 \\
\hline
\end{tabular}

\subsection{Annealing Treatment}

According to previous publications and $\mathrm{TiO}_{2}$ phase diagram, both the annealing ambient and pressure effect the temperature and speed of anatase to rutile phase transformation. However, the effect of annealing ambient on the phase transformation can be ignored because the variation of transformation temperature was less than $50{ }^{\circ} \mathrm{C}$. Moreover, the effect of annealing ambient on the phase transformation was dependent on the structural properties of anatase $\mathrm{TiO}_{2}$. In gas sensor applications, the working conditions of gas sensors were oxidizing conditions $\left(\mathrm{O}_{2}\right.$ or air $)$ at room pressure $(1 \mathrm{Bar})$. Therefore, in order to investigate the thermal stability, the as-deposited $\mathrm{TiO}_{2}$ films were calcined at a temperature in the range of $600-1100{ }^{\circ} \mathrm{C}$ in a pure oxygen ambient $(1 \mathrm{Bar})$ for $1 \mathrm{~h}$ with a rapid thermal annealing furnace (RTA, ULVAC-RIKO, MILA-3000, Yokohama, Japan). The conditions of annealing treatment are shown in Table 2.

Table 2. Conditions of annealing treatment.

\begin{tabular}{cc}
\hline Ambient & Pure Oxygen \\
Pressure (bar) & 1 \\
Annealing time (h) & 1 \\
Annealing temperature $\left({ }^{\circ} \mathbf{C}\right)$ & $600,800,1000,1100$ \\
Speed of warming up $\left({ }^{\circ} \mathbf{C} / \mathbf{m i n}\right)$ & 15 \\
Speed of cooling down $\left({ }^{\circ} \mathrm{C} / \mathrm{min}\right)$ & 10 \\
\hline
\end{tabular}

\subsection{Characterization}

The structural properties of $\mathrm{TiO}_{2}$ films were investigated by grazing incidence $X$-ray diffraction (GIXRD, ATX-G, Rigaku, Tokyo, Japan) with $\mathrm{Cu} \mathrm{K} \alpha$ X-ray source $\left(1.54184 \AA\right.$ ) at a $0.35^{\circ}$ incidence 
angle, Raman spectroscopy (LabRAM HR-800, Horiba Jobin Yvon, Longjumeau, France) with a $532.8 \mathrm{~nm}$ excitation laser, and X-ray photoelectron spectroscopy (XPS, AXIS-HS, Shimadzu/KRATOS, Kyoto, Japan) with $\mathrm{Mg} \mathrm{K} \alpha \mathrm{X}$-ray source $(1253.6 \mathrm{eV})$. The morphological properties of $\mathrm{TiO}_{2}$ films were evaluated by a field emission scanning electron microscope (FE-SEM, SU-8020, Hitachi, Tokyo, Japan). All measurements were carried out at room temperature.

\section{Results}

The GIXRD patterns of as-deposited $\mathrm{TiO}_{2}$ films and $\mathrm{TiO}_{2}$ films after annealing are shown in Figure 1a. Comparing as-deposited $\mathrm{TiO}_{2}$ films with $\mathrm{TiO}_{2}$ films calcined at 600,800 , and $1000{ }^{\circ} \mathrm{C}$, it was found that all of the diffraction peaks corresponded with the diffractions from (101), (200), (211), (201), (204), and (215) crystal planes of the anatase phase $\mathrm{TiO}_{2}$. This suggested that pure anatase phase $\mathrm{TiO}_{2}$ thin films were obtained by mist CVD. No anatase to rutile transformation was observed after $\mathrm{TiO}_{2}$ films calcined at 600,800 , and $1000{ }^{\circ} \mathrm{C}$. However, the $\mathrm{TiO}_{2}$ films calcined at $1100{ }^{\circ} \mathrm{C}$ showed a different GIXRD pattern. More peaks were observed at 2 theta of $27.57^{\circ}, 36.24^{\circ}, 41.44^{\circ}, 54.52^{\circ}$, and $56.73^{\circ}$ except the anatase phase peaks. Those peaks corresponded with rutile phase $\mathrm{TiO}_{2}$. This suggested that incomplete anatase to rutile transformation occurred under $1100{ }^{\circ} \mathrm{C}$ annealing.

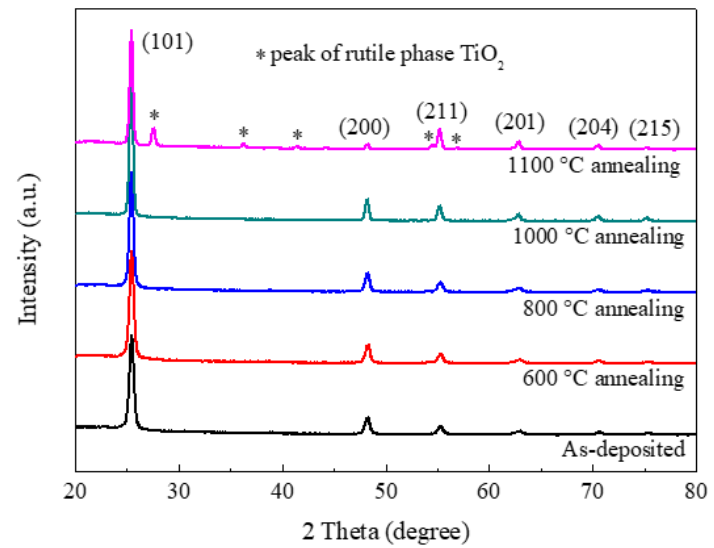

(a)

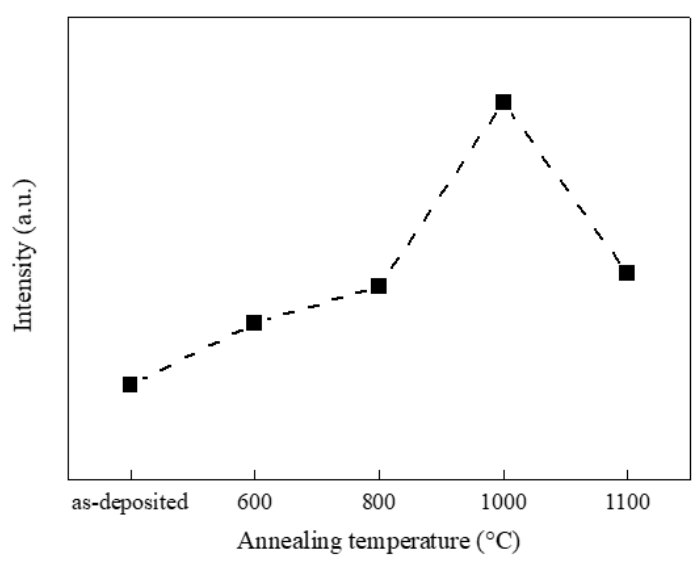

(b)

Figure 1. GIXRD results of as-deposited $\mathrm{TiO}_{2}$ films and $\mathrm{TiO}_{2}$ films after annealing. ((a) GIXRD patterns of $\mathrm{TiO}_{2}$ films; (b) (101) peak intensities of $\mathrm{TiO}_{2}$ films).

Compared with other diffraction peaks for all samples, the (101) peak located at 2 theta of $25.45^{\circ}$ was dominant with much higher intensity. The intensities of (101) peaks are shown in Figure $1 \mathrm{~b}$. Compared with as-deposited sample, the $\mathrm{TiO}_{2}$ films calcined at $600{ }^{\circ} \mathrm{C}$ showed higher (101) peak intensity. As the annealing temperature was increased from 600 to $1000{ }^{\circ} \mathrm{C}$, (101) peak intensity gradually increased. When the annealing temperature was increased from $1000^{\circ} \mathrm{C}$ to $1100{ }^{\circ} \mathrm{C}$, the $(101)$ peak intensity decreased due to the anatase to rutile transformation.

It is well-known that the results of XRD, including peak intensity and the full width at half maximum (FWHM) value, can be used to calculate the grain size and the thickness of defective layer [25-27]. According to the Scherrer equation (Equation (1)), the (101) orientation crystallite size (L) of anatase $\mathrm{TiO}_{2}$ can be calculated using the FWHM value $[25,26]$.

$$
\mathrm{L}=\frac{\mathrm{K} \lambda}{\beta \cos \theta}
$$

where $\mathrm{K}$ is a constant related to crystallite shape (taken as 0.89 for anatase), $\lambda$ the $\mathrm{X}$-ray wavelength in nanometer (taken as $0.154184 \mathrm{~nm}$ in this research), $\beta$ the FWHM value of diffraction peak in radians, and $\theta$ the diffraction angle. 
Figure 2 shows the average crystallite size along the (101) orientation calculated from GIXRD data. The calculated crystallite size of as-deposited $\mathrm{TiO}_{2}$ films was around $16.7 \mathrm{~nm}$. After annealing, the crystallite size of $\mathrm{TiO}_{2}$ films slightly increased. When the annealing temperature increased from $600{ }^{\circ} \mathrm{C}$ to $1100{ }^{\circ} \mathrm{C}$, the crystallite size of anatase $\mathrm{TiO}_{2}$ increased from $17.7 \mathrm{~nm}$ to $21.4 \mathrm{~nm}$ gradually. The increase in crystallite size could be attributed to several factors, including the anatase to rutile transformation. Compared with the increase of anatase crystallite size caused by anatase to rutile transformation reported in other publications $[20,28]$, the crystallite size increase of $\mathrm{TiO}_{2}$ synthesized by mist CVD was very gradual and slight. Therefore, we conclude that the increase in crystallite size was not caused by the phase transformation.

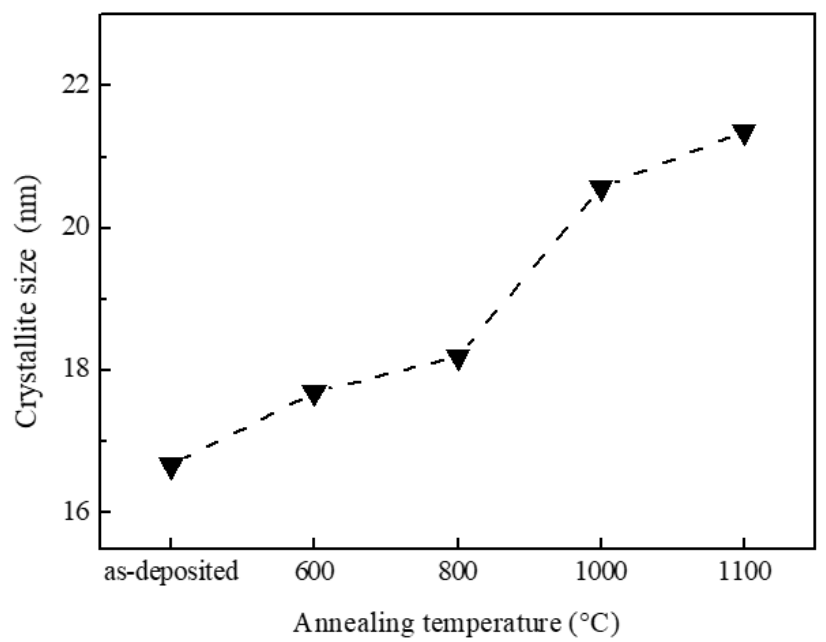

Figure 2. The (101) orientation crystallite sizes of as-deposited $\mathrm{TiO}_{2}$ films and $\mathrm{TiO}_{2}$ films after annealing.

Raman spectra of as-deposited $\mathrm{TiO}_{2}$ films and $\mathrm{TiO}_{2}$ films after annealing are shown in Figure 3a. Three peaks were observed in the spectra of as-deposited $\mathrm{TiO}_{2}$ films and $\mathrm{TiO}_{2}$ films calcined at 600 , 800 , and $1000{ }^{\circ} \mathrm{C}$. The peaks at around $395 \mathrm{~cm}^{-1}$ and $638 \mathrm{~cm}^{-1}$ corresponded with the $\mathrm{B}_{1 \mathrm{~g}}$ mode and $\mathrm{E}_{\mathrm{g}}$ mode of anatase phase $\mathrm{TiO}_{2}$ respectively $[29,30]$. The peaks at around $515 \mathrm{~cm}^{-1}$ corresponded with a doublet of the $\mathrm{A}_{1 \mathrm{~g}}$ and $\mathrm{B}_{1 \mathrm{~g}}$ modes of the anatase phase $\mathrm{TiO}_{2}[29,30]$. All of the peaks corresponded with the anatase phase $\mathrm{TiO}_{2}$, which indicated the as-deposited $\mathrm{TiO}_{2}$ films were pure anatase phase and the anatase to rutile transformation did not occur after calcination at 600,800 , and $1000{ }^{\circ} \mathrm{C}$. $\mathrm{For}^{\mathrm{TiO}} 2$ films calcined at $1100{ }^{\circ} \mathrm{C}$, as shown in the inserted image, some spots with a diameter of around $20 \mu \mathrm{m}$ were observed using the Raman system optical microscope. After checking these spots by Raman spectroscopy, two Raman peaks were observed and corresponded with rutile phase $\mathrm{TiO}_{2}$. Other areas were also measured and identified as anatase phase $\mathrm{TiO}_{2}$. This suggested that incomplete anatase-rutile transformation occurred during $1100{ }^{\circ} \mathrm{C}$ annealing. The results of Raman measurement were in agreement with those of the GIXRD measurement. Figure $3 b$ shows the relationship between the intensities of anatase Raman peaks and annealing temperatures. Compared with as-deposited sample, the $\mathrm{TiO}_{2}$ films showed higher Raman peak intensities after annealing at different temperatures. As the annealing temperature was increased from 600 to $1100{ }^{\circ} \mathrm{C}$, the intensities of all Raman peaks increased gradually. 


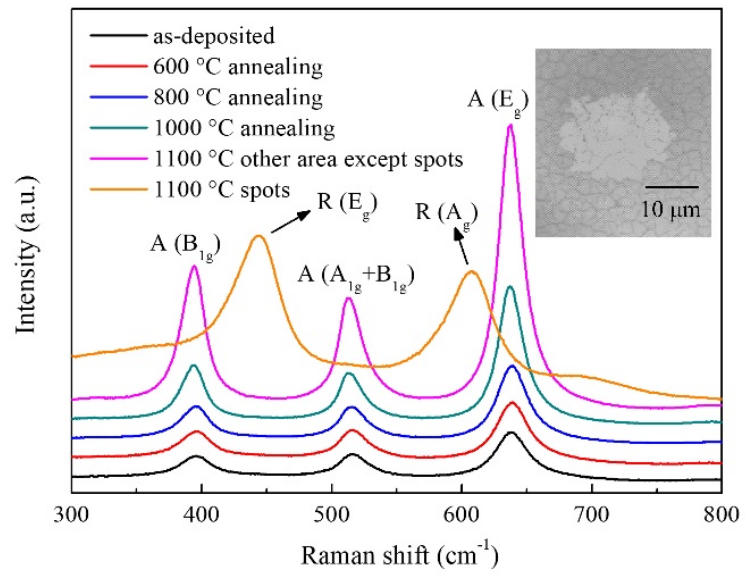

(a)

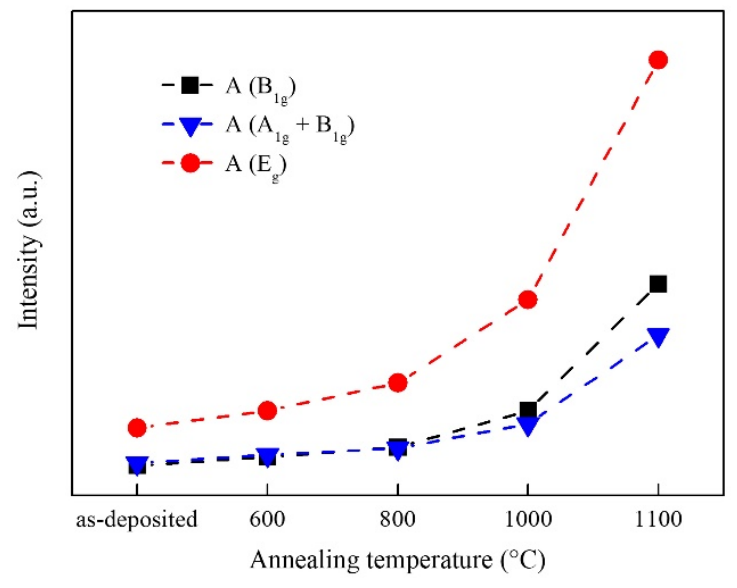

(b)

Figure 3. Raman results of as-deposited $\mathrm{TiO}_{2}$ films and $\mathrm{TiO}_{2}$ films after annealing. ((a) Raman spectra of $\mathrm{TiO}_{2}$ films; (b) Raman peak intensities of $\mathrm{TiO}_{2}$ films).

Since the presence of dopants may strongly affect the thermal stability of anatase phase $\mathrm{TiO}_{2}$, the purity of as-deposited sample was investigated by XPS. Figure 4 shows the XPS survey spectrum of as-deposited $\mathrm{TiO}_{2}$ films. As shown in the XPS survey spectrum, several distinct peaks were observed and corresponded with various electron orbitals of titanium and oxygen [21,31-34]. The XPS peak at around $521.3 \mathrm{eV}$ corresponded with the satellite peak of $\mathrm{O} 1 \mathrm{~s}$, which was attributed to $\mathrm{Mg} \mathrm{K} \alpha 3$. The Si 2 p peak was observed at around $101 \mathrm{eV}$ and attributed to the substrate (quartz glass). A C $1 \mathrm{~s}$ peak at around $284.5 \mathrm{eV}$ was observed due to environmental contamination. No peaks corresponding with other elements were observed, indicating that there were no obvious dopants in the as-deposited sample. Based on the results of XPS, the effects of impurities on the thermal stability of anatase phase $\mathrm{TiO}_{2}$ can be safely discounted.

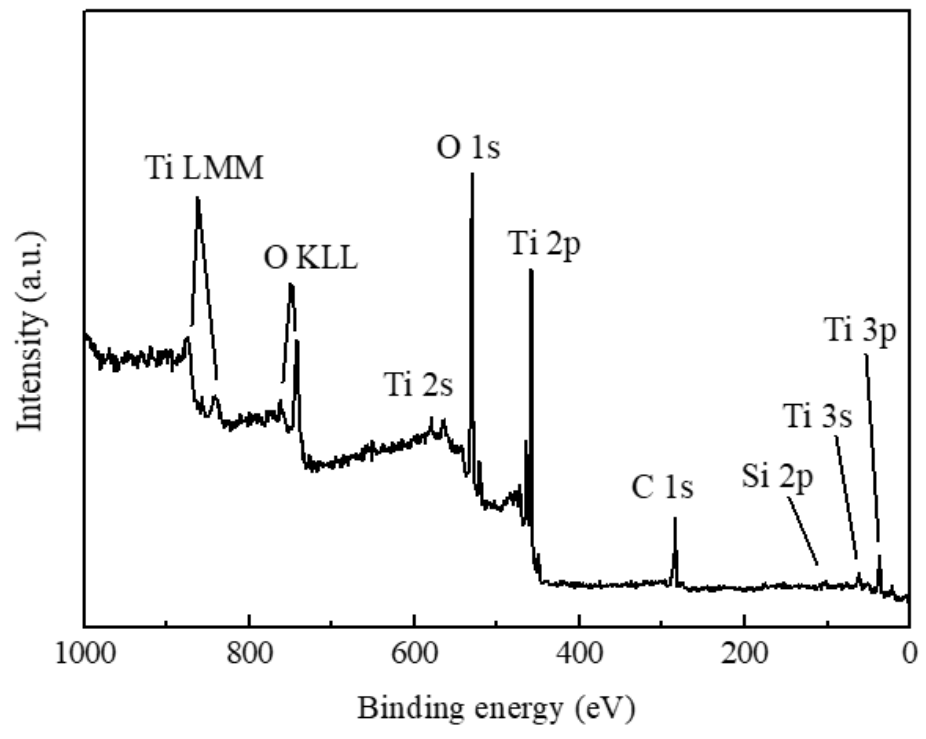

Figure 4. XPS survey spectrum of as-deposited $\mathrm{TiO}_{2}$ films.

The top view FE-SEM images of as-deposited $\mathrm{TiO}_{2}$ films and $\mathrm{TiO}_{2}$ films after annealing are shown in Figure 5. It was confirmed that the as-deposited $\mathrm{TiO}_{2}$ film exhibited a uniform surface. As shown in Figure $5 \mathrm{a}$, the intertwined $\mathrm{TiO}_{2}$ nanosheets were observed in as-deposited $\mathrm{TiO}_{2}$ film. Compared with as-deposited sample, the morphology of $\mathrm{TiO}_{2}$ films calcined at $600{ }^{\circ} \mathrm{C}$ and $800{ }^{\circ} \mathrm{C}$ including the length and thickness of sheet-like grains showed little change. As the annealing temperature was 
increased from $800{ }^{\circ} \mathrm{C}$ to $1000{ }^{\circ} \mathrm{C}$, the thickness of $\mathrm{TiO}_{2}$ nanosheets increased slightly. However, the length of $\mathrm{TiO}_{2}$ nanosheets showed little variation. As shown in Figure $5 \mathrm{f}$, the $\mathrm{TiO}_{2}$ films calcined at $1100{ }^{\circ} \mathrm{C}$ showed different morphology as other samples. Some spots with a diameter of around $20 \mu \mathrm{m}$ were observed, which was similar to the image obtained by the optical microscope in Raman system. The detail of spots and other areas were checked and shown in Figure 5e,g respectively. According to Raman results, these spots were identified as rutile phase $\mathrm{TiO}_{2}$, and other areas were identified as anatase phase. However, the morphology of anatase phase area was different to other anatase phase samples. The grain size of anatase phase area was much bigger than other samples. This suggested that the incomplete anatase-rutile transformation occurred during $1100{ }^{\circ} \mathrm{C}$ annealing, which corresponds well to the results of the GIXRD and Raman measurement.
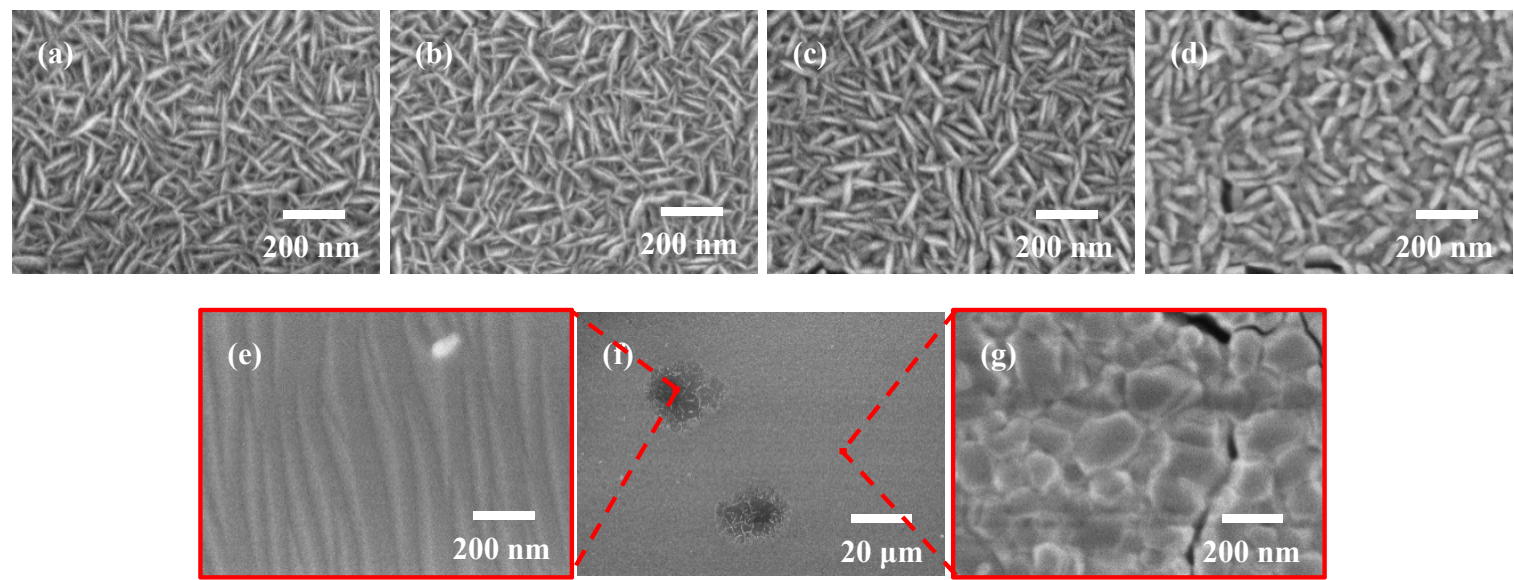

Figure 5. FE-SEM images of as-deposited $\mathrm{TiO}_{2}$ films (a) and $\mathrm{TiO}_{2}$ films calcined at different temperatures ((b) $600{ }^{\circ} \mathrm{C}$; (c) $800{ }^{\circ} \mathrm{C}$; (d) $1000{ }^{\circ} \mathrm{C}$; (e-g) $\left.1100{ }^{\circ} \mathrm{C}\right)$.

According to related research [6,22], if the anatase phase $\mathrm{TiO}_{2}$ is not thermodynamically stable at the critical temperature, the anatase to rutile transformation will occur immediately. At the beginning of phase transformation, the reaction rate is almost a constant. Accordingly, the rutile phase $\mathrm{TiO}_{2} \mathrm{can}$ be detected after several minutes annealing, which has been proved by some publications [6,20]. In this research, the anatase phase $\mathrm{TiO}_{2}$ kept its sheet-like structure after one hour annealing at $1000{ }^{\circ} \mathrm{C}$, and rutile phase $\mathrm{TiO}_{2}$ was not found by GIXRD and Raman measurement. Therefore, we can conclude that the anatase phase $\mathrm{TiO}_{2}$ films synthesized in this research showed high thermal stability up to $1000{ }^{\circ} \mathrm{C}$.

According to the GIXRD results, the as-deposited $\mathrm{TiO}_{2}$ film showed a small crystallite size of around $16.7 \mathrm{~nm}$. As mentioned in the introduction, anatase phase is thermodynamically more stable than rutile phase for such crystallite size. Moreover, the rutile transformation would be unlikely to occur if the crystallite size does not increase, which maybe a reason for the high thermal stability of $\mathrm{TiO}_{2}$ films. As mentioned in the introduction, the presence of $\{112\}$ facets in anatase phase $\mathrm{TiO}_{2}$ will decrease the thermal stability of anatase phase $\mathrm{TiO}_{2}$. Therefore, a diffraction peak that corresponded with $\{112\}$ facets was not observed in the GIXRD pattern of as-deposited sample, which also improved the thermal stability of $\mathrm{TiO}_{2}$ film.

Another reason for high temperature stabilized pure anatase $\mathrm{TiO}_{2}$ film could be the fabrication method. As annealing temperature was increased from 600 to $1000{ }^{\circ} \mathrm{C}$, the morphology of $\mathrm{TiO}_{2}$ films including the length and thickness of sheet-like grains did not show much change. These unique sheet-like grains with fewer interfaces had a great influence on the anatase to rutile phase transformation. Fewer grain interfaces can suppress the phase transformation. The packing characteristics of the sheet-like $\mathrm{TiO}_{2}$ grains suppressed the interface nucleation of the rutile phase and significantly limited the phase transformation at a relatively high temperature. Moreover, the weak connections among sheet-like grains worked as barriers, which blocked anatase-rutile transformation. 
As the temperature increased to over $1000{ }^{\circ} \mathrm{C}$, the interface and weak connections could not suppress the anatase to rutile transformation. The sheet-like grains were merged into a large grain with many voids.

\section{Conclusions}

Pure anatase phase $\mathrm{TiO}_{2}$ films with high thermal stability were successfully synthesized by mist CVD method. Sheet-like grains were observed in obtained $\mathrm{TiO}_{2}$ film. As calcined temperature was increased from 600 to $1000{ }^{\circ} \mathrm{C}$, the $\mathrm{TiO}_{2}$ films did not show any obvious difference in terms of morphological and structural properties. $\mathrm{The}_{\mathrm{TiO}}$ films were in the pure anatase phase until the annealing temperature reached to $1000{ }^{\circ} \mathrm{C}$. Anatase to rutile transformation of $\mathrm{TiO}_{2}$ film occurred at a temperature of $1100{ }^{\circ} \mathrm{C}$. It was shown that the sheet-like grains, small crystallite size, and the absence of $\{112\}$ facets might contribute to the high temperature stability of $\mathrm{TiO}_{2}$ film. Anatase $\mathrm{TiO}_{2}$ films with high temperature stability therefore demonstrate great potential for application in high temperature gas sensors.

Author Contributions: Conceptualization, Q.Z.; methodology, Q.Z.; investigation, Q.Z.; data curation, Q.Z.; writing —original draft preparation, Q.Z.; writing—review \& editing, C.L.; visualization, C.L.; supervision, C.L.; project administration, C.L.; funding acquisition, C.L. All authors have read and agreed to the published version of the manuscript.

Funding: This research was funded by the Ministry of Education, Culture, Sports, Science and Technology (MEXT) in Japan, grant number [17K06394].

Acknowledgments: The authors gratefully acknowledge the financial support by Grant-in-Aid for Scientific Research from the Ministry of Education, Culture, Sports, Science and Technology (MEXT), Japan.

Conflicts of Interest: The authors declare no conflict of interest.

\section{References}

1. Fujishima, A.; Rao, T.N.; Tryk, D.A. Titanium dioxide photocatalysis. J. Photochem. Photobiol. C 2000, 1, 1-21. [CrossRef]

2. Ghosh, T.B.; Dhabal, S.; Datta, A.K. On crystallite size dependence of phase stability of nanocrystalline $\mathrm{TiO}_{2}$. J. Appl. Phys. 2003, 94, 4577-4582. [CrossRef]

3. Bai, Y.; Mora-Sero, I.; De Angelis, F.; Bisquert, J.; Wang, P. Titanium dioxide nanomaterials for photovoltaic applications. Chem. Rev. 2014, 114, 10095-10130. [CrossRef] [PubMed]

4. Li, J.; Liu, L.; Sham, T.-K. 2D XANES-XEOL Spectroscopy studies of morphology-dependent phase transformation and corresponding luminescence from hierarchical $\mathrm{TiO}_{2}$ nanostructures. Chem. Mater. 2015, 27, 3021-3029. [CrossRef]

5. Liu, S.; $\mathrm{Yu}$, J.; Jaroniec, M. Anatase $\mathrm{TiO}_{2}$ with dominant high-energy $\{001\}$ facets: Synthesis, properties, and applications. Chem. Mater. 2011, 23, 4085-4093. [CrossRef]

6. Hanaor, D.A.; Sorrell, C.C. Review of the anatase to rutile phase transformation. J. Mater. Sci. 2011, 46, 855-874. [CrossRef]

7. Garzella, C.; Comini, E.; Tempesti, E.; Frigeri, C.; Sberveglieri, G. $\mathrm{TiO}_{2}$ thin films by a novel sol-gel processing for gas sensor applications. Sens. Actuator B Chem. 2000, 68, 189-196. [CrossRef]

8. Grover, I.S.; Singh, S.; Pal, B. Stable anatase $\mathrm{TiO}_{2}$ formed by calcination of rice-like titania nanorod at $800{ }^{\circ} \mathrm{C}$ exhibits high photocatalytic activity. RSC Adv. 2014, 4, 24704-24709. [CrossRef]

9. Winardi, S.; Mukti, R.R.; Kumar, K.N.P.; Wang, J.; Wunderlich, W.; Okubo, T. Critical nuclei size, initial particle size and packing effect on the phase stability of sol-peptization-gel-derived nanostructured titania. Langmuir 2010, 26, 4567-4571. [CrossRef]

10. Sun, F.; Zhou, W.; Tian, G.; Pan, K.; Miao, X.; Li, Y.; Zhang, G.; Li, T.; Fu, H. Fabrication of rice-like porous anatase $\mathrm{TiO}_{2}$ with high thermal stability and enhanced photocatalytic performance. ChemCatChem 2012, 4, 844-850. [CrossRef]

11. Seeley, Z.M.; Bandyopadhyay, A.; Bose, S. Titanium dioxide thin films for high temperature gas sensors. Thin Solid Films 2010, 519, 434-438. [CrossRef] 
12. Gönüllü, Y.; Haidry, A.A.; Saruhan, B. Nanotubular $\mathrm{Cr}$-doped $\mathrm{TiO}_{2}$ for use as high-temperature $\mathrm{NO}_{2}$ gas sensor. Sens. Actuator B Chem. 2015, 217, 78-87. [CrossRef]

13. Barnard, A.S.; Curtiss, L.A. Prediction of $\mathrm{TiO}_{2}$ nanoparticle phase and shape transitions controlled by surface chemistry. Nano Lett. 2005, 5, 1261-1266. [CrossRef] [PubMed]

14. Zhang, H.; Banfield, J.F. Thermodynamic analysis of phase stability of nanocrystalline titania. J. Mater. Chem. 1998, 8, 2073-2076. [CrossRef]

15. Gouma, P.I.; Mills, M.J. Anatase-to-rutile transformation in titania powders. J. Am. Ceram. Soc. 2001, 84, 619-622. [CrossRef]

16. Penn, R.L.; Banfield, J.F. Formation of rutile nuclei at anatase $\{112\}$ twin interfaces and the phase transformation mechanism in nanocrystalline titania. Am. Miner. 1999, 84, 871-876. [CrossRef]

17. Zhou, Y.; Fichthorn, K.A. Microscopic view of nucleation in the anatase-to-rutile transformation. J. Phys. Chem. C 2012, 116, 8314-8321. [CrossRef]

18. Lee, G.H.; Zuo, J.M. Growth and phase transformation of nanometer-sized titanium oxide powders produced by the precipitation method. J. Am. Ceram. Soc. 2004, 87, 473-479. [CrossRef]

19. Zhao, Y.; Zhang, Y.; Liu, H.; Ji, H.; Ma, W.; Chen, C.; Zhu, H.; Zhao, J. Control of exposed facet and morphology of anatase crystals through $\mathrm{TiO}_{\mathrm{x}} \mathrm{F}_{\mathrm{y}}$ precursor synthesis and impact of the facet on crystal phase transition. Chem. Mater. 2014, 26, 1014-1018. [CrossRef]

20. Ding, X.; Liu, X. Correlation between anatase-to-rutile transformation and grain growth in nanocrystalline titania powders. J. Mater. Res. 1998, 13, 2556-2559. [CrossRef]

21. Sun, Y.; Egawa, T.; Zhang, L.; Yao, X. High anatase-rutile transformation temperature of anatase titania nanoparticles prepared by metalorganic chemical vapor deposition. Jpn. J. Appl. Phys. 2002, 41, L945-L948. [CrossRef]

22. Shannon, R.D.; Pask, J.A. Kinetics of the anatase-rutile transformation. J. Am. Ceram. Soc. 1965, 48, 391-398. [CrossRef]

23. Zhang, Q.; Li, C. Pure anatase phase titanium dioxide films prepared by mist chemical vapor deposition. Nanomaterials 2018, 8, 827. [CrossRef] [PubMed]

24. Zhang, Q.; Li, C. Effect of substrates on structural properties of pure anatase phase titanium dioxide thin films prepared by mist chemical vapor deposition. ECS J. Solid State Sci. Technol. 2018, 7, P654-P659. [CrossRef]

25. Fewster, P.F. X-ray analysis of thin films and multilayers. Rep. Prog. Phys. 1996, 59, 1339-1407. [CrossRef]

26. Monshi, A.; Foroughi, M.R.; Monshi, M.R. Modified Scherrer equation to estimate more accurately nano-crystallite size using XRD. World J. Nano Sci. Eng. 2012, 2, 154-160. [CrossRef]

27. Sohrabpoor, H.; Elyasi, M.; Aldosari, M.; Gorji, N.E. Modeling the $\mathrm{PbI}_{2}$ formation in perovskite solar cells using XRD/XPS patterns. Superlatt. Microstruct. 2016, 97, 556-561. [CrossRef]

28. Traversa, E.; Di Vona, M.L.; Licoccia, S.; Sacerdoti, M.; Carotta, M.C.; Crema, L.; Martinelli, G. Sol-gel processed $\mathrm{TiO}_{2}$-based nano-sized powders for use in thick-film gas sensors for atmospheric pollutant Monitoring. J. Sol-Gel Sci. Technol. 2001, 22, 167-179. [CrossRef]

29. Balachandran, U.; Eror, N.G. Raman spectra of titanium dioxide. J. Solid State Chem. 1982, 42, 276-282. [CrossRef]

30. Danish, R.; Ahmed, F.; Koo, B.H. Rapid synthesis of high surface area anatase Titanium Oxide quantum dots. Ceram. Int. 2014, 40, 12675-12680. [CrossRef]

31. Ingo, G.M.; Dire, S.; Babonneau, F. XPS studies of $\mathrm{SiO}_{2}-\mathrm{TiO}_{2}$ powders prepared by sol-gel process. Appl. Surf. Sci. 1993, 70, 230-234. [CrossRef]

32. Nagaraj, G.; Brundha, D.; Chandraleka, C.; Arulpriya, M.; Kowsalya, V.; Sangavi, S.; Jayalakshmi, R.; Tamilarasu, S.; Murugan, R. Facile synthesis of improved anatase $\mathrm{TiO}_{2}$ nanoparticles for enhanced solar-light driven photocatalyst. SN Appl. Sci. 2020, 2, 734. [CrossRef]

33. Yu, J.; Xiang, Q.; Zhou, M. Preparation, characterization and visible-light-driven photocatalytic activity of Fe-doped titania nanorods and first-principles study for electronic structures. Appl. Catal. B 2009, 90, 595-602. [CrossRef]

34. Atashbar, M.Z.; Sun, H.T.; Gong, B.; Wlodarski, W.; Lamb, R. XPS study of Nb-doped oxygen sensing $\mathrm{TiO}_{2}$ thin films prepared by sol-gel method. Thin Solid Films 1998, 326, 238-244. [CrossRef]

(C) 2020 by the authors. Licensee MDPI, Basel, Switzerland. This article is an open access article distributed under the terms and conditions of the Creative Commons Attribution (CC BY) license (http://creativecommons.org/licenses/by/4.0/). 